\title{
Penerapan Keadilan Restoratif Dalam Penyelesaian Perkara Kecelakaan Lalu Lintas Berat Di Kepolisian Resort Metro Jakarta Pusat
}

\author{
Rahman Amin', Muhammad Fikri Al Aziz², Iren Manalu³
}

123Fakultas Hukum, Universitas Bhayangkara Jakarta Raya

Korespondensi: rahman.amin2013@gmail.com

Info Artikel

Naskah diterima : 9 Des 2019 | Revisi : 28 Jan 2020 | Disetujui : 10 Feb 2020

\begin{abstract}
Abstrak
Penyelesaian perkara pidana melalui keadilan restoratif pada tahap penyidikan diatur dalam Surat Edaran Kapolri Nomor 8 Tahun 2018 tentang Penerapan Keadilan Restoratif (Restorative Justice) Dalam Penyelesaian Perkara Pidana, yang mengatur bahwa penyelesaian perkara melalui keadilan restoratif sebelum Surat Pemberitahuan Dimulainya Penyidikan dikirimkan ke Jaksa Penuntut Umum dan penerapannya terhadap semua tindak pidana yang tidak menimbulkan korban manusia sehingga menimbulkan masalah dalam penerapannya. Penelitian ini adalah penelitian yuridis normatif-empiris dengan menggunakan pendekatan perundang-undangan dan pendekatan kasus. Teknik pengumpulan data primer melalui penelitian lapangan dengan dan penelitian kepustakaan untuk mendapatkan data sekunder. Hasil penelitian bahwa penerapan keadilan restoratif dalam penyelesaian perkara kecelakaan lalu lintas berat di Polres Metro Jakarta Pusat dilakukan oleh Penyidik setelah adanya perdamaian antara pelaku dan keluarga korban yang dilakukan setelah Penyidik mengirim Surat Pemberitahuan Dimulainya Penyidikan ke Jaksa Penuntut Umum Kejari Jakarta Pusat sehingga penanganan perkara tidak dilanjutkan. Faktor-faktor yang mempengaruhi penerapan keadilan restoratif dalam penyelesaian perkara kecelakaan lalu lintas berat terdiri dari faktor penegak hukum yaitu pengetahuan dan pemahaman Penyidik terhadap peraturan perundang-undangan yang berlaku, faktor substansi hukum yakni substansi Surat Edaran Kapolri yang mengatur tentang syarat materiil yang tidak mengakomodir penyelesaian perkara dengan korban manusia dan syarat formiil tentang jangka waktu dalam penerapan keadilan restoratif hanya terhadap tindak pidana pada tahap penyidikan sebelum dikirimkan Surat Pemberitahuan Dimulainya Penyidikan, dan faktor budaya hukum masyarakat berkaitan dengan nilainilai, sikap dan perilaku dalam kehidupan masyarakat sehingga mempengaruhi pengambilan keputusan untuk menyelesaiakan perkara kecelakaan lalu lintas yang dialaminya melalui keadilan restoratif.
\end{abstract}

Kata kunci: keadilan restoratif, kecelakaan lalu lintas berat 


\begin{abstract}
The settlement of criminal cases through re storative justice at the investigation stage is regulated in the Circular of the National Police Chief Number 8 of 2018 concerning the Implementation of Restorative Justice in the Settlement of Criminal Cases, which regulates that the settlement of cases through restorative justice before the Notice of Commencement of Investigation is sent to the Public Prosecutor and its application to all criminal offenses that do not cause human victims resulting in problems in their application. This research is a normative-empirical juridical study using the legislative approach and case approach. Primary data collection techniques through field research and library research to get secondary data. The results of the study show that the application of restorative justice in the settlement of cases of heavy traffic accidents at the Central Jakarta Metro Police was conducted by the Investigator after the peace between the perpetrator and the victim's family was carried out after the Investigator sent a Notice of Investigation Commencement to the Central Jakarta Prosecutor General Prosecutor so that the handling of the case was not continued. Factors that influence the application of restorative justice in the settlement of cases of heavy traffic accidents consist of law enforcement factors, namely the knowledge and understanding of the Investigator against the applicable laws and regulations, legal substance factors, namely the substance of the National Police Circular which regulates the material requirements that do not accommodate settlement cases with human victims and formal requirements regarding the time period in implementing restorative justice only against criminal acts at the investigation stage before being sent the Notice of Commencement of Investigation, and the cultural legal factors of the community relating to values, attitudes and behavior in people's lives so as to influence decision making for resolve the traffic accident case that he experienced through restorative justice.
\end{abstract}

Keywords: restorative justice, heavy traffic accident

\title{
I. PENDAHULUAN
}

\section{A. Latar Belakang}

Indonesia adalah negara hukum sebagaimana tercantum dalam Pasal 1 Ayat

3 Undang-Undang Dasar 1945 yang secara tegas menyatakan bahwa Negara Republik Indonesia adalah negara hukum, dengan demikian dalam praktik kehidupan bermasyarakat, berbangsa dan bernegara harus memenuhi dan mewujudkan persyaratan dan prinsip-prinsip yang terdapat dalam negara hukum.

Sebagai negara hukum, maka semua adalah pelaku, pendukung dan pelaksana sebagaimana telah digariskan bahwa para penyelenggara negara dan pemerintahan wajib dilaksanakan berdasarkan kepada ketentuan hukum. ${ }^{1}$

Hukum merupakan norma atau kaidah yang berisi perintah serta larangan sifatnya mengikat yang mengatur kehidupan manusia dalam masyarakat. Dalam

\footnotetext{
${ }^{1}$ Padmo Wahjono, Indonesia Negara Berdasarkan Atas Hukum, Ghalia Indonesia, Jakarta, 1986, hlm 21.
} 
norma hukum terdapat sanksi yang ditujukan bagi setiap orang yang melanggar ketentuan hukum tersebut. Untuk mencapai tujuan hukum yaitu untuk mewujudkan keadilan, kemanfaatan dan kepastian, maka norma-norma hukum harus ditegakan. Penegakan hukum suatu proses dilakukannya segala upaya demi tegaknya atau berfungsinya norma-norma hukum secara nyata sebagai pedoman perilaku dalam lalu lintas atau hubungan antara individu dalam kehidupan masyarakat.

Upaya penegakan hukum pidana dilaksanakan dalam wadah sistem peradilan pidana (criminal justice system) yaitu suatu sistem dalam masyarakat untuk mengendalikan dan menanggulangi masalah kejahatan. Menanggulangi adalah usaha mengendalikan kejahatan agar berada dalam batas-batas toleransi masyarakat, yang terdiri dari empat komponen lembaga yaitu kepolisian, kejaksaan, pengadilan dan lembaga pemasyarakatan dengan tujuan untuk mencegah masyarakat menjadi korban kejahatan, menyelesaikan kasus kejahatan yang terjadi, dan mengusahakan agar pelaku kejahatan tidak mengulangi kejahatannya. ${ }^{2}$

Dewasa ini seiring dengan perkembangan ilmu pengetahuan dan teknologi menyebabkan peningkatan tindak pidana dalam kehidupan masyarakat yang disebabkan semakin meningkatnya penggunaan sarana teknologi dalam menunjang segala aktivitas kehidupan masyarakat. Salah satu jenis tindak pidana yang marak terjadi dalam kehidupan masyarakat adalah perkara kecelakaan lalu lintas yang sering menjadi pemberitaan baik di media cetak maupun elektronik yang terjadi di berbagai wilayah di Indonesia baik di daerah perkotaan maupun di pedesaan dengan melibatkan berbagai lapisan masyarakat dan menimbulkan kerugian baik materiil maupun korban manusia sehingga perkara kecelakaan lalu lintas menjadi suatu permasalahan bangsa Indonesia.

Salah satu upaya dalam penyelesaian tindak pidana yang terjadi dalam kehidupan masyarakat tidak hanya melalui upaya penegakan hukum, namun melalui pendekatan keadilan restoratif yang berbeda dengan sistem peradilan pidana konvensional, di mana pendekatan ini menitikberatkan partisipasi langsung pelaku, korban dan masyarakat dalam proses penyelesaian perkara pidana. Keadilan restoratif, menawarkan pandangan dan pendekatan berbeda dalam memahami dan menangani suatu tindak pidana. Dalam pandangan keadilan restoratif, tindak pidana pada dasarnya sama seperti pandangan hukum pidana,

\footnotetext{
${ }^{2}$ Marjono Reksodiputro dalam Romli Atmasasmita, Sistem Peradilan Pidana Kontemporer, Kencana, Jakarta, 2011, hlm 2-3.
} 
namun dalam proses pencarian keadilan yang terjadi atas suatu perkara pidana melibatkan korban, pelaku dan masyarakat dalam usaha perbaikan, rekonsiliasi dan penjaminan keberlangsungan usaha perbaikan tersebut. ${ }^{3}$

Sehubungan dengan hal tersebut, Polri mengeluarkan Surat Edaran Kapolri Nomor: SE/8/VII/2018 tentang Penerapan Keadilan Restoratif (Restorative Justice) Dalam Penyelesaian Perkara Pidana, yang mengatur bahwa perkara yang dapat diselesaikan melalui mekanisme keadilan restoratif adalah perkara pidana dengan kerugian kecil yang merupakan kategori tindak pidana ringan, dan tidak dapat diterapkan terhadap tindak pidana berat yang mengakibatkan korban manusia. Selain itu, penerapan keadilan restoratif hanya dapat dilakukan terhadap tindak pidana sebelum Penyidik mengirim Surat Pemberitahuan Dimulainya Penyidikan (SPDP) ke Jaksa Penuntut Umum. Dengan demikian, penyelesaian perkara kecelakaan lalu lintas berat dengan korban meninggal dunia melalui keadilan restoratif yang dilakukan oleh Penyidik Satuan Lalu Lintas Polres Metro Jakarta Pusat berbanding terbalik dengan ketentuan dalam Surat Edaran Kapolri tersebut sehingga terjadi kesenjangan antara apa yang seharusnya (das sollen) dan apa yang menjadi kenyataan (das sein).

Berdasarkan uraian tersebut di atas, penting untuk dikaji bagaimana penerapan keadilan restoratif dalam penyelesaian perkara kecelakaan lalu lintas berat dengan korban meninggal dunia yang dilakukan oleh Penyidik Satuan Lalu Lintas di Polres Metro Jakarta Pusat melalui upaya perdamaian antara pelaku dan korban sehingga penanganan terhadap perkara kecelakaan lalu lintas tersebut dihentikan penyidikannya dan tidak dilanjutkan ke Jaksa Penuntut Umum Kejari Jakarta Pusat dan faktor-faktor yang mempengaruhinya, sehingga dapat diketahui apakah yang menjadi dasar pertimbangan Penyidik dalam penyelesaian perkara kecelakaan lalu lintas tersebut yang dapat digunakan sebagai bahan masukan untuk melakukan revisi terhadap ketentuan yang mengatur keadilan restoratif pada tahap penyidikan tindak pidana guna mewujudkan keadilan, kepastian dan kemanfaatan hukum bagi masyarakat.

\section{B. Tujuan dan Metode}

Tujuan dari penelitian ini adalah untuk mengetahui penerapan keadilan restoratif dalam penyelesaian perkara kecelakaan lalu lintas berat di Polres Metro

\footnotetext{
3 Jonlar Purba, Penegakan Hukum Terhadap Tindak Pidana Bermotif Ringan Dengan Restorative Justice, Jala Permata Aksara, Jakarta, 2017, hlm. 55.
} 
Jakarta Pusat dan untuk mengetahui faktor-faktor yang mempengaruhi penerapan keadilan restoratif dalam penyelesaian perkara kecelakaan lalu lintas berat di Polres Metro Jakarta Pusat. Penelitian ini adalah penelitian yuridis normatif-empiris dengan menggunakan pendekatan perundang-undangan (statute approach) dan pendekatan kasus (case approach). ${ }^{4}$ Teknik pengumpulan data primer melalui penelitian lapangan (field research) dengan menggunakan metode wawancara (interview) untuk memperoleh informasi dengan mengajukan pertanyaan kepada sampel penelitian sesuai dengan permasalahan yang diteliti. ${ }^{5}$ Teknik pengumpulan data sekunder dilakukan melalui penelitian kepustakaan (library research) atau studi dokumen untuk memperoleh data sekunder yang berhubungan dengan pokok permasalahan yang diteliti. ${ }^{6}$ Teknik analisis data dalam penelitian ini adalah yuridis-kualitatif. Analisis secara kualitatif yaitu dengan mengkaji data-data yang didapat dari hasil penelitian baik data sekunder maupun data primer secara sistematis serta konsisten untuk mencapai suatu kejelasan dari permasalahan yang akan dibahas.7 $^{7}$

\section{PEMBAHASAN}

\section{A. Tinjauan Pustaka}

\section{Pengertian Tindak Pidana dan Unsur-Unsurnya}

Istilah tindak pidana berasal dari hukum pidana Belanda yaitu strafbaar feit yang terdapat dalam Wetboek van Strafrecht $(W v S)$ Belanda, karena Kitab UndangUndang Hukum Pidana (KUHP) yang berlaku Indonesia saat ini merupakan Wetboek van Strafrecht voor Indonesie yang berasal dari Wetboek van Strafrecht Nederland (KUHP Belanda) yang diberlakukan di Indonesia melalui asas konkordansi, sehingga peristilahan dan bahasanya berasal dari Bahasa Belanda yang kemudian diterjemahkan ke dalam bahasa Indonesia. ${ }^{8}$

Sebagai terjemahan strafbaar feit digunakan istilan tindak pidana yang diperkenalkan oleh pihak pemerintah c.q Depatemen Kehakiman yang kemudian banyak digunakan dalam undang-undang tindak pidana khusus, misalnya Undang-

\footnotetext{
${ }^{4}$ Peter Mahmud Marzuki, Penelitian Hukum, Jakarta : Kencana, 2013, hlm. 133-134.

${ }^{5}$ Ronny Hanitijo Soemitro, Metode Penelitian Hukum dan Jurimetri, Jakarta : Ghalia Indonesia, 1990, hlm. 57.

${ }^{6}$ Bambang Sunggono, Metodologi Penelitian Hukum, Jakarta : PT. RajaGrafindo Persada, 2013, hlm. $112-113$

${ }^{7}$ Burhan Ashshofa, Metode Penelitian Hukum, Jakarta : PT.Rineka Cipta, 2004, hlm. 20.

8 Teguh Prasetyo, Hukum Pidana, Raja Grafindo Persada, Jakarta, 2011, hlm. 47.
} 
Undang tindak pidana korupsi, Undang-Undang tindak pidana narkotika, UndangUndang pidana terorisme dan sebagainya. Istilah tindak pidana menunjukan pengertian gerak-gerik tingkah laku jasmani seseorang. Hal tersebut terdapat juga seseorang untuk tidak berbuat, akan tetapi dengan tidak berbuatnya dia, dia telah melakukan tindak pidana. Dengan demikian, tindak pidana adalah perbuatan yang oleh aturan hukum dilarang dan diancam dengan pidana, baik aktif dalam arti melakukan sesuatu yang dilarang oleh hukum, dan juga perbuatan yang bersifat pasif yaitu tidak berbuat sesuatu yang sebenarnya diharuskan oleh hukum. ${ }^{9}$

Unsur-unsur tindak pidana menurut Moeljatno sebagai penganut pandangan dualistis yang memisahkan antara perubatan pidana dan pertanggungjawaban pidana, bahwa pada hakikatnya setiap perbuatan pidana harus terdiri dari unsurunsur lahiriah (fakta) oleh perbuatan, mengandung kelakuan dan akibat yang ditimbulkan karenanya. Keduanya memunculkan kejadian dalam alam lahir (dunia). Di samping kelakuan dan akibat, untuk adanya perbuatan pidana perlu adanya hal ikhwal atau keadaan tertentu yang menyertai perbuatan. Atas dasar hal tersebut, Moeljatno menyimpulkan bahwa unsur-unsur atau elemen perbuatan pidana adalah $^{10}$ :

1. Kelakuan dan akibat (perbuatan).

2. Hal ikhwal atau keadaan yang menyertai perbuatan.

3. Keadaan tambahan yang menyertai perbuatan.

4. Unsur melawan hukum yang obyektif.

5. Unsur melawan hukum yang subjektif.

\section{Pengertian dan Jenis-Jenis Kecelakaan Lalu Lintas}

Istilah lalu lintas menurut Pasal 1 angka 1 Undang-Undang Nomor 22 Tahun 2009 tentang Lalu Lintas dan Angkutan Jalan, memberikan pengertian Lalu Lintas dan Angkutan Jalan adalah satu kesatuan sistem yang terdiri atas Lalu Lintas, Angkutan Jalan, Jaringan Lalu Lintas dan Angkutan Jalan, Prasarana Lalu Lintas dan Angkutan Jalan, Kendaraan, Pengemudi, Pengguna Jalan, serta pengelolaannya. Lebih lanjut ketentuan Pasal 1 angka 2 Undang-Undang Nomor 22 Tahun 2009 tentang Lalu Lintas dan Angkutan Jalan memberikan pengertian Lalu lintas adalah

\footnotetext{
${ }^{9}$ Ibid, hlm. 49-50.

${ }^{10}$ Moeljatno, Asas-Asas Hukum Pidana, Rineka Cipta, Jakarta, 2008, hlm. 69.
} 
gerak kendaraan dan orang di ruang lalu lintas jalan. Kemudian dalam Pasal 1 angka 3 menjelaskan bahwa angkutan jalan adalah perpindahan orang dan/atau barang dari satu tempat ke tempat lain dengan menggunakan kendaraan di ruang lalu lintas jalan.

Membahas tentang lalu lintas tentunya tidak dapat dipisahkan dari permasalahan yang sering terjadi di jalan yaitu kecelakaan lalu lintas. World Health Organization (WHO) memberikan pengertian bahwa kecelakaan lalu lintas adalah kejadian dimana sebuah kendaraan bermotor bertabrakan dengan benda lain dan menyebabkan kerusakan. Kadang kecelakaan ini dapat mengkibatkan luka-luka atau kematian manusia, dimana kecelakaan lalu lintas merupakan kejadian yang sulit untuk diprediksi kapan dan dimana akan terjadinya atau merupakan kejadian yang tidak terduga kapan dan dimana terjadinya serta tidak diharapkan oleh setiap orang. ${ }^{11}$

Undang-Undang Nomor 22 Tahun 2009 tentang Lalu Lintas dan Angkutan Jalan, Pasal 1 angka 24 memberikan pengertian kecelakaan lalu lintas adalah suatu peristiwa di jalan yang tidak diduga dan tidak disengaja melibatkan kendaraan dengan atau tanpa pengguna jalan lain yang mengakibatkan korban manusia dan/atau kerugian harta benda. Selanjutnya berkaitan dengan penggolongan kecelakaan lalu lintas, Pasal 229 Undang-Undang Nomor 22 Tahun 2009 tentang Lalu Lintas dan Angkutan Jalan, sebagai berikut:

1) Kecelakaan lalu lintas digolongkan atas:

a. Kecelakaan lalu lintas ringan;

b. Kecelakaan lalu lintas sedang;

c. Kecelakaan lalu lintas berat;

2) Kecelakaan lalu lintas ringan sebaimana dimaksud pada ayat (1) huruf a merupakan kecelakaan yang mengakibatkan kerusakan kendaraan dan/atau barang;

3) Kecelakaan lalu lintas sedang sebagaimana dimaksud pada ayat (1) huruf b merupakan kecelakaan yang mengakibatkan luka ringan dan kerusakan kendaraan dan/atau barang;

11 Abadi Dwi Saputra, Studi Tingkat Kecelakaan Lalu Lintas Jalan di Indonesia Berdasarkan Data KNKT (Komite Nasional Kecelakaan Transportasi) Dari Tahun 2007-2016, Warta Penelitian Perhubungan, Volume 29, Nomor 2, Juli-Desember 2017, hlm. 1. 
4) Kecelakaan lalu lintas berat sebagaimana dimaksud pada ayat (1) huruf c merupakan kecelakaan yang mengakibatkan korban meninggal dunia atau luka berat.

Penggolongan kecelakaan lalu lintas lebih lanjut diatur dalam Peraturan Kapolri Nomor 15 Tahun 2013 tentang Tata Cara Penanganan Kecelakaan Lalu Lintas, Pasal 4 bahwa kecelakaan lalu lintas digolongkan atas kecelakaan ringan, kecelakaan sedang dan kecelakaan berat. Pasal 5 bahwa kecelakaan ringan apabila mengakibatkan kerusakan kendaraan dan/atau barang. Sedangkan kecelakaan sedang diatur dalam Pasal 6 sebagai berikut:

1) Kecelakaan sedang sebagaimana dimaksud pada Pasal 4 huruf b, apabila mengakibatkan luka ringan dan kerusakan kendaraan dan/atau barang;

2) Luka ringan sebagaimana dimaksud pada ayat (1) terdiri atas:

a. Luka yang mengakibatkan korban menderita sakit yang tidak memerlukan perawatan inap di rumah sakit; atau

b. Selain yang diklasifikasikan dalam luka berat.

Selanjutnya berkaitan dengan kecelakaan berat diatur dalam Pasal 7 Peraturan Kapolri Nomor 15 Tahun 2013 tentang Tata Cara Penanganan Kecelakaan Lalu Lintas sebagai berikut:

1) Kecelakaan berat sebagaimana dimaksud dalam Pasal 4 huruf c, apabila mengakibatkan luka berat atau meninggal dunia;

2) Luka berat sebagaimana dimaksud pada ayat (1) terdiri atas:

a. Jatuh sakit dan tidak ada harapan sembuh sama sekali atau menimbulkan bahaya maut;

b. Tidak mampu terus-menerus untuk menjalankan tugas jabatan atau pekerjaan;

c. Kehilangan salah satu panca indera;

d. Menderita cacat berat atau lumpuh;

e. Terganggu daya piker selama 4 (empat) minggu lebih;

f. Gugur atau matinya kandungan seorang perempuan; atau

g. Luka yang membutuhkan rawat inap lebih dari 30 (tiga puluh) hari.

3) Korban meninggal dunia sebagaimana dimaksud pada ayat (1) terdiri atas:

a. Meninggal dunia di TKP;

b. Meninggal dunia dalam perjalanan ke rumah sakit; atau 
c. Meninggal dunia karena luka yang diderita dalam masa perawatan selama 30 (tiga puluh) hari sejak terjadinya kecelakaan lalu lintas.

\section{Pengertian, Tugas dan Kewenangan Polri.}

Istilah kepolisian dalam Pasal 1 angka 1 Undang-Undang Nomor 2 Tahun 2002 tentang Polri, adalah segala hal ihwal yang berkaitan dengan fungsi dan lembaga polisi sesuai dengan peraturan perundang-undangan. Tujuan kepolisian adalah mewujudkan keamanan dalam negeri yang meliputi terpeliharanya keamanan dan ketertiban masyarakat, tertib dan tegaknya hukum, terselenggaranya perlindungan, pengayoman dan pelayanan kepada masyarakat serta terbinanya ketentraman masyarakat dengan menjunjung tinggi hak asasi manusia. ${ }^{12}$ Tugas pokok Polri adalah memelihara kemanan dan ketertiban masyarakat, menegakan hukum dan memberikan perlindungan, pengayoman dan pelayanan kepada masyarakat. ${ }^{13}$

Untuk melaksanakan tugas pokoknya dalam penegakan hukum, Polri mempunyai wewenang di bidang proses pidana menurut Pasal 16 Ayat (1) UndangUndang Nomor 2 Tahun 2002 tentang Kepolisian Negara Republik Indonesia, yaitu :

a. Melakukan penangkapan, penahanan, penggeladahan dan penyitaan;

b. Melarang setiap orang untuk meninggalkan atau memasuki tempat kejadian perkara untuk kepentingan penyidikan;

c. Membawa dan menghadapkan orang kepada penyidik dalam rangka penyidikan;

d. Menyuruh berhenti orang yang dicurigai dan menanyakan serta memeriksa tanda pengenal diri;

e. Melakukan pemeriksaan dan penyitaan surat;

f. Memanggil orang untuk didengar dan diperiksa sebagai tersangka atau saksi;

g. Mendatangkan orang ahli yang diperlukan dalam hubungannya dengan pemeriksaan perkara;

h. Mengadakan penghentian penyidikan;

i. Menyerahkan berkas perkara kepada penuntut umum;

j. Mengajukan secara langsung kepada pejabat Imigrasi yang berwenang

\footnotetext{
12 Pasal 4 Undang-Undang Nomor 2 Tahun 2002 tentang Polri.
}

${ }^{13}$ Pasal 13 Undang-Undang Nomor 2 Tahun 2002 tentang Polri. 
ditempat pemeriksaan Imigrasi dalam keadaan mendesak atau mendadak untuk mencegah atau menangkal orang yang disangka melakukan tindak pidana;

k. Memberikan petunjuk dan bantuan penyidikan kepada penyidik pegawai negeri sipil serta menerima hasil penyidikan penyidik pegawai negeri sipil untuk diserahkan kepada penuntut umum; dan

l. Mengadakan tindakan lain menurut hukum yang bertanggung jawab.

\section{Pengertian dan Model Keadilan Restoratif}

Istilah restorative justice atau keadilan restoratif merupakan suatu model pendekatan yang muncul pada era tahun 1960-an dalam upaya penyelesaian perkara pidana yang berbeda dengan pendekatan yang dipakai dalam sistem peradilan pidana konvensional yang melibatkan partisipasi langsung pelaku, korban dan masyarakat dalam proses penyelesaian perkara pidana, dimana pendekatan keadilan restoratif sebagai pergeseran paling mutakhir dari berbagai model dan mekanisme yang bekerja dalam sistem peradilan pidana, sehingga pendekatan keadilan restoratif merupakan suatu paradigma yang dapat dipakai untuk menjawab ketidapuasan atas bekerjanya sistem peradilan pidana saat ini. ${ }^{14}$

Keadilan restoratif memahami kejahatan tidak semata sebagai pelanggaran terhadap hukum negara, melainkan lebih sebagai pelanggaran terhadap keadilan yang berlaku di masyarakat. Titik fokus penyelesaianannya tidak diarahkan untuk menghukum pelaku kejahatan karena telah melanggar hukum negara, melainkan pada upaya-upaya untuk memulihkan hubungan-hubungan sosial dan keadilan masyarakat yang rusak akibat kejahatan. Metode keadilan restoratif menekankan keterlibatan aktif pihak-pihak yang terdampak (langsung maupun tidak) dari kejahatan yang terjadi untuk menemukan jalan penyelesaian, dan tidak bergantung pada penegak hukum negara dengan mekanisme formal yang berlaku, melainkan ditandai pada proses yang bersifat informal dan kesukarelaan. ${ }^{15}$

Keadilan restoratif (restorative justice) dalam menyelesaikan suatu perkara terdiri beberapa model atau bentuk yang diterapkan di berbagai negara yaitu: ${ }^{16}$

1. Mediasi pelaku-korban (Victim offender mediation) atau disebut

\footnotetext{
14 Jonlar Purba, Op Cit, hlm. 55-56.

15 Afthonul Afif, Pemaafan, Rekonsiliasi \& Restorative Justice; Diskursus Perihal Pelanggaran di Masa Lalu dan Upaya-Upaya Melampauinya, Pustaka Pelajar, Yogyakarta, 2015, hlm. 328-329.

16 Jonlar Purba, Op Cit, hlm. 63-66.
} 
dialog/pertemuan/rekonsiliasi pelaku-korban biasanya dilakukan pertemuan antara pelaku dan korban yang menghadirkan mediator terlatih. Model ini digunakan baik kasus kecil untuk mengurangi tumpukan perkara, maupun kasus serius untuk memfasilitasi pengampunan dan proses penyembuhan yang lebih mendalam baik untuk korban maupun pelaku;

2. Pertemuan kelompok (Family group conferencing), merupakan lingkaran partisipan yang lebih luas daripada mediasi pelaku-korban, yaitu menambah orang yang dikaitkan dengan pihak-pihak utama, seperti melibatkan teman, keluarga, dan profesional. Model ini paling tepat untuk kasus-kasus kenakalan anak, yang didesain untuk menawarkan perencanaan dan pembentukan putusan yang kooperatif dan untuk membangun kembali jaringan kerja dukungan keluarga;

3. Pertemuan restoratif (restorative conferencing), juga melibatkan partisipan yang lebih luas ketimbang mediasi pelaku-korban. Model ini bersifat volunter (sukarela) yang terdiri dari pelaku, korban, keluarga para pihak dan teman untuk mencapai konsekuensi dan restitusi (ganti kerugian);

4. Dewan peradilan masyarakat (community restorative boards) atau yang disebut komite peradilan masyarakat yang merupakan kelompok kecil yang dipersiapkan melalui pelatihan intensif yang dilaukan masyarakat. Karakter model ini yaitu dimasukannya anggota masyarakat dalam proses, pemulihan penderitaan akibat kejahatan dan reintegrasi pelaku kedalam masyarakat;

5. Lingkaran atau sistem restoratif (restorative circles), pendekatan ini melibatkan banyak lingkaran partisipan yang lebih luas daripada pertemuan pelaku-korban yang konvensional, yang dimulai dengan membangun sistem restoratif di lingkungan tempat lingkaran akan diselenggarakan.

Dari uraian di atas, maka pendekatan keadilan restoratif dalam penanganan perkara pidana pada prinsipnya menempatkan keadilan restoratif yaitu upaya pemulihan (restorasi) terhadap kerugian yang ditimbulkan dari perbuatan yang dilakukan oleh pelaku sebagai nilai dasar yang digunakan dalam merespon suatu perkara pidana. Dalam hal ini dalam keadilan restoratif mensyaratkan adanya keseimbangan antara kepentingan pelaku dan kepentingan korban serta memperhitungkan pula dampak penyelesaian perkara pidana tersebut melalui keadilan restofatif dalam kehidupan masyarakat sehingga penerapan keadilan 
restoratif tidak memberikan dampak luas bagi masyarakat. ${ }^{17}$

\section{Dasar Hukum Penerapan Keadilan Restoratif Dalam Penyelesaian Perkara Pidana}

Penerapan keadilan restoratif (restorative justice) dalam sistem peradilan pidana khususnya dalam perkara yang melibatkan anak sebagai pelaku tindak pidana diatur dalam Undang-Undang Nomor 11 Tahun 2012 tentang Sistem Peradilan Pidana Anak, Pasal 7 pada pokoknya bahwa terhadap dalam penanganan perkara pada tahap penyidikan, penuntutan dan pemeriksaan di pengadilan yang melibatkan anak sebagai pelaku tindak pidana, maka wajib untuk diupayakan diversi dengan persyaratan yaitu tindak pidana dengan ancama pidana penjara di bawah 7 (tujuh) tahun dan bukan merupakan pengulangan tindak pidana, di mana ketentuan tersebut hanya berlaku dalam perkara yang melibatkan anak sebagai pelaku tindak pidana.

Untuk merespon harapan masyarakat pencari keadilan khususnya dalam penyelesaian perkara pidana melalui perdamaian sekaligus sebagai dasar hukum yang menjadi pedoman bagi penyidik dalam menerapkan keadilan restoratif dalam penyelesaian tindak pidana, Polri telah mengeluarkan Surat Edaran Kapolri Nomor: SE/8/VII/2018 tanggal 27 Juli 2018 tentang Penerapan Keadilan Restoratif (Restorative Justice) Dalam Penyelesaian Perkara Pidana. Ketentuan Poin 3 a dan b Surat Edaran Kapolri tersebut mengatur tentang syarat materiil penerapan keadilan restoratif yaitu:

1. Tidak menimbulkan keresahan masyarakat dan tidak ada penolakan masyrakat;

2. Tidak berdampak konflik sosial;

3. Adanya pernyataan dari semua pihak yang terlibat untuk tidak keberatan dan melepaskan hak menuntutnya di hadapan hukum;

4. Prinsip pembatas pada pelaku yakni tingkat kesalahan pelaku tidak relatif berat (kesalahan bukan dalam bentuk kesengajaan) dan bukan residivis, dan pada tindak pidana dalam proses penyelidikan dan penyidikan sebelum SPDP dikirim ke Penuntut Umum.

Selain syarat materiil, Surat Edaran Kapolri tersebut juga mengatur syarat

${ }^{17}$ Lilik Mulyadi, Media Penal Dalam Sistem Peradilan Pidana Indonesia, Alumni, Bandung, 2015, hlm. 63-64. 
formil penerapan keadilan dalam penerapan keadilan restoratif yaitu :

1. Surat permohonan perdamaian antara kedua belah pihak (pelapor dan terlapor);

2. Surat pernyataan perdamaian dan penyelesaian perselisihan para pihak yang berperkara (pelapor dan/atau keluarga pelapor, terlapor dan/atau keluarga terlapor dan perwakilan dari tokoh masyarakat) diketahui oleh atasan penyidik;

3. Berita acara pemeriksaan tambahan pihak yang berperkara setelah dilakukan penyelesaian perkara melalui keadilan restoratif (restorative justice);

4. Rekomendasi gelar perkara khusus yang menyetujui penyelesaian keadilan restoratif (restorative justice);

5. Pelaku tidak keberatan atas tanggungjawab, ganti rugi, atau dilakukan dengan sukarela;

6. Semua tindak pidana dapat dilakukan restorative justice terhadap kejahatan umum yang tidak menimbulkan korban manusia.

\section{B. Penerapan Keadilan Restoratif dalam Penyelesaian Perkara Kecelakaan}

Lalu Lintas dan faktor-faktor yang mempengaruhinya

\section{Penerapan Keadilan Restoratif dalam Penyelesaian Perkara Kecelakaan}

\section{Lalu Lintas}

Untuk membahas penerapan keadilan restoratif dalam penyelesaian perkara kecelakaan lalu lintas berat di Polres Metro Jakarta Pusat, Peneliti akan diuraikan penanganan perkara kecelakaan lalu lintas yang dilakukan oleh Penyidik Unit Laka Lantas Satuan Lalu Lintas Polres Metro Jakarta Pusat, di mana peneliti akan menggunakan salah satu perkara kecelakaan lalu lintas berat yang terjadi di wilayah hukum Polres Metro Jakarta Pusat pada tahun 2019 untuk dijadikan bahan analisis berdasarkan ketentuan yang diatur dalam Surat Edaran Kapolri Nomor 8 Tahun 2018 tentang Penerapan Keadilan Restoratif (Restorative Justice) Dalam Penyelesaian Perkara Pidana yang menjadi pedoman bagi Penyidik Unit Laka Lantas Satuan Lalu Lintas Polres Metro Jakarta Pusat dalam penerapan keadilan restoratif penyelesaian perkara kecelakaan lalu lintas.

Salah satu contoh kasus penerapan keadilan restoratif dalam penyelesaian perkara kecelakan lalu lintas berat yang ditangani oleh Penyidik Unit Laka Lantas 
Satlantas Polres Metro Jakarta Pusat adalah perkara kecelakaan lalu lintas yang terjadi pada tanggal 29 Mei 2019 sekitar pukul 20.30 WIB bertempat di Jln. Cideng Timur, Gambir Jakarta Pusat, dengan kronologis pada saat Tersangka ARTOWIKOCY MUHAMMAD KEIRAN PRASETYO sedang mengemudikan mobil BMW No. Pol B 108 TY tiba-tiba diberhentikan oleh anggota Polsek Gambir a.n. AIPDA DEDY APRIANTO karena menerobos traffic light, namun karena Tersangka ARTOWIKOCY MUHAMMAD KEIRAN PRASETYO sedang melihat aplikasi google maps di hand phone miliknya sehingga menabrak AIPDA DEDY APRIANTO sampai terjatuh di jalan raya dan menyebabkan korban mengalami pendarahan di kepala sehingga dirawat di RSUD Tarakan dan akhirnya korban a.n. AIPDA DEDY APRIANTO meninggal dunia di Bhayangkara TK. I RS. Sukanto.

Atas peristiwa kecelakaan lalu lintas tersebut, Penyidik Unit Laka Lantas Satlantas melaksanakan penanganan awal di tempat kejadian perkara Laka Lantas di Jalan Cideng Timur Jakarta Pusat yaitu melakukan tindakan pertama di tempat kejadian perkara, melakukan pertolongan kepada korban a.n. AIPDA DEDY APRIANTO, dilanjutkan dengan kegiatan olah TKP Laka Lantas, mengamankan pelaku dan barang bukti berupa 1 (satu) unit Kendaraan Sedan BMW No. Pol B 108 TY, mencari saksi-saksi di TKP, menggambar sket TKP, mengecek dan memintakan visum et repertum luka korban ke rumah sakit dan kemudian membuat Laporan Polisi Nomor: LP/188/33-LK/V/2019/LPJP tanggal 29 Mei 2019 atas dugaan tindak pidana karena kelalaiannya mengakibatkan kecelakaan lalu lintas yang mengakibatkan orang lain luka berat sebagaimana dimaksud dalam Pasal 310 ayat (4) Undang-Undang Nomor 22 Tahun 2009 tentang Lalu Lintas dan Angkutan Jalan.

Tindak lanjut penanganan perkara kecelakan lalu lintas tersebut, Penyidik Unit Laka Lantas Polres Metro Jakarta Pusat telah mengeluarkan Surat Perintah Penyelidikan Nomor: Sprin/188/V/2019/LPJP tanggal 29 Mei 2019 dan dari hasil penyelidikan dituangkan dalam Laporan Hasil Penyelidikan sebagai bahan pelaksanaan gelar perkara tanggal 29 Mei 2019 tentang meningkatkan status penanganan perkara dari tahap penyelidikan ke tahap penyidikan dengan Tersangka ARTOWIKOCY MUHAMMAD KEIRAN PRASETYO. Penyidik kemudian mengeluarkan Surat Perintah Penyidikan Nomor: Sprin/188/V/2019/LPJP tanggal 29 Mei 2019 dan telah mengirimkan Surat Pemberitahuan Dimulainya Penyidikan ke Kajari Jakarta Pusat sesuai surat Nomor: B/188/VI/2019/LLJP tanggal 30 Juni 2019 dengan Tersangka ARTOWIKOCY MUHAMMAD KEIRAN PRASETYO. 
Dalam proses penyidikan, Penyidik telah melakukan upaya paksa yaitu telah melakukan penangkapan terhadap Tersangka ARTOWIKOCY MUHAMMAD KEIRAN PRASETYO sesuai Surat Perintah Penangkapan Nomor: SP. Kap/188/V/2019/LLJP tanggal 29 Mei 2019, telah melakukan penyitaan sesuai Surat Perintah Penyitaan Nomor: S.gas/188/V/2019/LLJP tanggal 29 Mei 2019 terhadap 1 (satu) unit kendaraan Sedan BMW No. Pol B 108 TY dan 1 (satu) lembar STNK BMW No. Pol B 108 TY, telah melakukan penahanan terhadap Tersangka ARTOWIKOCY MUHAMMAD KEIRAN PRASETYO sesuai Surat Perintah Penahanan Nomor: SPP/02/V/2019/LLJP tanggal 30 Mei 2019, dan telah melakukan pemanggilan dan pemeriksaan terhadap saksi-saksi guna kepentingan pembuktian perkara hingga penyelesaian berkas perkara hasil penyidikan selanjutnya dikirimkan ke Jaksa Penuntut Umum Kejari Jakarta Pusat.

Adapun penerapan keadilan restoratif terhadap perkara kecelakaan lalu lintas tersebut dilakukan selama proses penyidikan berlangsung yang diawali dengan upaya komunikasi dari pihak keluarga Tersangka ARTOWIKOCY MUHAMMAD KEIRAN PRASETYO kepada pihak keluarga korban a.n. AIPDA DEDY APRIANTO yang pada saat itu korban sedang menjalani perawatan di rumah sakit dan akhirnya korban a.n. AIPDA DEDY APRIANTO meninggal dunia. Pihak keluarga Tersangka ARTOWIKOCY MUHAMMAD KEIRAN PRASETYO akhirnya dapat menjalin komunikasi dengan pihak keluarga korban dan menyampaikan maksud untuk menyelesaikan perkara kecelakaan lalu lintas tersebut secara kekeluargaan hingga kemudian terjadi pertemuan antara pihak keluarga korban dan pihak keluarga tersangka pada tanggal 12 Agustus 2019 bertempat di ruang pertemuan Satuan Lalu Lintas Polres Metro Jakarta Pusat.

Pertemuan antara kedua belah pihak tersebut menghasilkan kesepakatan untuk menyelesaikan permasalahan kecelakaan lalu lintas tersebut secara kekeluargaan yang dituangkan dalam surat kesepakatan perdamaian yang ditandatangani oleh kedua belah pihak dan disaksikan perwakilan dari kedua belah pihak. Isi surat perjanjian tersebut menyatakan bahwa kedua belah pihak menyadari bahwa kecelakaan lalu lintas yang terjadi merupakan musibah yang tidak bisa dihindarkan dan telah menjadi kehendak dari ALLAH SWT sehingga kedua belah pihak bersepakat untuk menyelesaikan permasalahan tersebut secara damai dan kekeluargaan, di mana pihak keluarga Tersangka ARTOWIKOCY MUHAMMAD KEIRAN PRASETYO bersedia untuk membantu biaya perdidikan yang 
diperlukan oleh anak-anak korban a.n. AIPDA DEDY APRIANTO sesuai kemampuan yang dimiliki yaitu sebesar Rp 150.000.000,- (seratus lima puluh juta rupiah), dan atas kesepakatan perdamaian tersebut maka pihak keluarga korban tidak akan melakukan tuntutan hukum apapun kepada Tersangka ARTOWIKOCY MUHAMMAD KEIRAN PRASETYO baik secara perdata maupun secara pidana di kemudian hari atas peristiwa kecelakaan lalu lintas tersebut.

Berdasarkan surat kesepakatan perdamaian tersebut, kemudian kedua belah pihak mengajukan permohonan kepada Penyidik Unit Laka Lantas Polres Metro Jakarta Pusat yang menangani perkara kecelakaan lalu lintas tersebut agar penyelesaian perkara kecelakaan tersebut tidak dilanjutkan penanganannya karena telah terjadi perdamaian. Permohonan tersebut kemudian diajukan kepada Kanit Laka Lantas yang selanjutnya dilaporkan ke Kasat Lantas Polres Metro Jakarta Pusat selaku atasan Penyidik. Setelah disetujui, kemudian Penyidik Unit Laka Lantas Polres Metro Jakarta Pusat berkoordinasi dengan Jaksa Penuntut Umum Kejari Jakarta Pusat sehubungan dengan upaya penyelesaian perkara kecelakaan lalu lintas yang sedang ditangani tersebut melalui penerapan keadilan restoratif karena telah terjadi perdamaian antara kedua belah pihak, dan selanjutnya Penyidik Unit Laka Lantas Polres Metro Jakarta Pusat memutuskan untuk tidak melanjutkan penanganan perkara kecelakaan lalu lintas tersebut.

Berdasarkan uraian penyelesaian perkara lalu lintas melalui keadilan restoratif yang dilakukan oleh Penyidik Unit Laka Lantas Polres Metro Jakarta Pusat tersebut, ditinjau dari syarat materiil dalam Surat Edaran Kapolri Nomor 8 Tahun 2018 tentang Penerapan Keadilan Restoratif (Restorative Justice) Dalam Penyelesaian Perkara Pidana, bahwa penerapan keadilan restoratif hanya dapat diterapkan selama dalam proses penyelidikan dan penyidikan sebelum Surat Pemberitahuan Dimulainya Peyidikan (SPDP) dikirimkan ke Jaksa Penuntut Umum. Dengan demikian, terhadap penanganan perkara tersebut di atas, Penyidik mengambil kebijakan meskipun penanganan perkara telah dikirimkan SPDP ke Jaksa Penuntut Umum Kejari Jakarta Pusat, namun karena telah terjadi perdamaian antara pihak keluarga pelaku dan korban untuk tidak melakukan tuntutan hukum, sehingga Penyidik memutuskan untuk tidak melanjutkan penanganan perkara kecelakaan lalu lintas tersebut.

Ditinjau dari syarat formiil dalam Surat Edaran Kapolri Nomor 8 Tahun 2018 tentang Penerapan Keadilan Restoratif (Restorative Justice) Dalam Penyelesaian Perkara Pidana bahwa semua tindak pidana dapat dilakukan keadilan restoratif 
terhadap kejahatan umum yang tidak menimbulkan korban manusia, sedangkan dalam perkara kecelakaan lalu lintas yang dilakukan oleh Tersangka ARTOWIKOCY MUHAMMAD KEIRAN PRASETYO telah mengakibatkan korban a.n. AIPDA DEDY APRIANTO meninggal dunia. Dengan demikian terhadap perkara kecelakaan lalu lintas tersebut tidak memenuhi syarat formiil untuk dapat diselesaikan melalui keadilan restoratif, namun demikian Penyidik Unit Laka Lantas Polres Metro Jakarta Pusat mengambil kebijakan untuk tidak melanjutkan penanganan perkara kecelakaan lalu lintas tersebut dengan pertimbangan bahwa perkara kecelakaan lalu lintas tersebut telah telah diselesaikan secara kekeluargaan dan kedua belah pihak telah sepakat untuk tidak melanjutkan perkara tersebut.

Selanjutnya, ditinjau dari mekanisme penerapan keadilan restoratif sebagaimana diatur dalam Surat Edaran Kapolri Nomor 8 Tahun 2018 tentang Penerapan Keadilan Restoratif (Restorative Justice) Dalam Penyelesaian Perkara, bahwa tahapan penerapan keadilan restoratif dilakukan setelah adanya kesepakatan kedua belah pihak ditindaklanjuti dengan mekanisme gelar perkara khusus dengan mengundang kedua belah pihak, dan hasil dari gelar perkara khusus menjadi dasar Penyidik untuk mengeluarkan Surat Perintah Penghentian Penyelidikan atau Penyidikan dan Surat Ketetapan Penghentian Penyelidikan atau Penyidikan. Dengan demikian, dalam penanganan perkara kecelakaan lalu lintas tersebut, Penyidik tidak melaksanakan tahapan penyelesaian perkara sesuai yang telah ditentukan yaitu tidak melaksanakan gelar perkara khusus sebagai dasar untuk mengeluarkan Surat Perintah Penyidikan dan Surat Ketetapan Penghentian Penyidikan, sehingga penghentian penyidikan terhadap perkara tersebut tidak dilengkapi dengan administrasi penyidikan sebagai dasar hukum yang kuat atas penghentian penanganan perkara tersebut.

\section{Faktor-Faktor yang mempengaruhi Penerapan Keadilan Restoratif dalam Penyelesaian Perkara Kecelakaan Lalu Lintas}

Untuk mengetahui faktor-faktor yang mempengaruhi penerapan keadilan restoratif dalam penyelesaian perkara kecelakaan lalu lintas berat di Polres Metro Jakarta Pusat dapat ditinjau pada tahap aplikasi atau penerapan keadilan restoratif itu sendiri yang dilaksanakan oleh Penyidik Unit Laka Lantas Polres Metro Jakarta Pusat ketika menangani perkara kecelakaan lalu lintas di lapangan. Hal ini berarti faktorfaktor yang mempengaruhi penerapan keadilan restoratif dalam penyelesaian perkara 
kecelakaan lalu lintas dapat ditemukan dan diidentifikasi berdasarkan dari pengalaman empiris yang secara langsung dialami oleh Penyidik Unit Laka Lantas Polres Metro Jakarta Pusat ketika menangani perkara kecelakaan lalu lintas sehubungan dengan upaya penyelesaian perkara kecelakaan lalu lintas yang terjadi dalam kehidupan masyarakat.

Berdasarkan hasil wawancara yang Peneliti lakukan dengan Kanit Laka Lantas Satlantas Polres Metro Jakarta Pusat a.n. IPTU SETIYONO dan hasil observasi terhadap penanganan perkara kecelakaan lalu lintas yang dilakukan oleh Penyidik pada Unit Laka Lantas Polres Metro Jakarta Pusat maka Peneliti menyimpulkan bahwa penerapan keadilan restoratif dalam penyelesaian perkara kecelakaan lalu lintas di Polres Metro Jakarta Pusat dipengaruhi tiga faktor yaitu faktor penegak hukum, faktor substansi hukum dan faktor budaya hukum, yang dapat diuraikan dalam pembahasan di bawah ini.

\section{a. Faktor Penegak Hukum}

Faktor penegak hukum adalah faktor yang berasal dari aparat penegak hukum yang melaksanakan ketentuan peraturan perundang-undangan dalam praktik penegakan hukum, dalam hal ini Penyidik Unit Laka Lantas Polres Metro Jakarta Pusat yang menangani perkara kecelakaan lalu lintas sejak tahap awal penanganan di tempat kejadian perkara yang ditindaklanjuti dengan proses penyelidikan dan penyidikan terhadap perkara kecelakaan lalu lintas yang terjadi sampai dengan upaya penyelesaian perkara kecelakaan lalu lintas tersebut melalui penerapan keadilan restoratif sehingga penanganan terhadap kecelakaan lalu lintas tersebut dihentikan proses penyelidikan atau penyidikannya dan tidak dilanjutkan ke Jaksa Penuntut Umum Kejari Jakarta Pusat.

Faktor penegak hukum berkaitan dengan pengetahuan dan pemahaman terhadap ketentuan peraturan perundang-undangan yang berlaku berkaitan dengan penanganan perkara kecelakaan lalu lintas sebagaimana diatur dalam Undang-Undang Nomor 8 Tahun 1981 tentang Kitab Undang-Undang Hukum Acara Pidana (KUHAP) sebagai hukum acara pidana yang berlaku secara umum dalam pelaksanaan penyelidikan dan penyidikan tindak pidana, Peraturan Kapolri Nomor 14 Tahun 2012 tentang Manajemen Penyidikan Tindak Pidana sebagai peraturan teknis pelaksanakan penyidikan dan penyidikan tindak pidana di lingkungan Polri, Peraturan Kapolri Nomor 15 Tahun 2013 tentang 
Tata Cara Penanganan Kecelakaan Lalu Lintas, dan petunjuk teknis penerapan keadilan restoratif yang diatur dalam Surat Edaran Kapolri Nomor 8 Tahun 2018 tentang Penerapan Keadilan Restoratif (Restorative Justice) Dalam Penyelesaian Perkara Pidana.

Aspek pengetahuan dan pemahaman Penyidik terhadap ketentuan peraturan perundang-undangan yang berlaku mempunyai pengaruh yang signifikan dalam proses penyelidikan dan penyidikan tindak pidana sehingga sangat diperlukan sebagai bekal bagi Penyidik Unit Laka Lantas Polres Metro Jakarta Pusat ketika menangani perkara kecelakaan lalu lintas yang terjadi sejak tahap awal penanganan perkara di tempat kejadian perkara, tahap penyelidikan dan penyidikan terhadap perkara kecelakaan lalu lintas hingga penyelesaian perkara melalui penerapan keadilan restoratif. Tanpa dibekali dengan pengetahuan dan pemahaman yang memadai terhadap ketentuan peraturan perundang-undangan yang berlaku maka pelaksanaaan tugas Penyidik Unit Laka Lantas Satlantas Polres Metro Jakarta Pusat ketika menerapkan keadilan resoratif dalam penyelesaian perkara kecelakaan lalu lintas akan tidak sesuai dengan ketentuan hukum yang berlaku karena ketidaktahuan atau kurangnya pemahaman Penyidik yang menangai perkara kecelakaan lalu lintas tersebut.

\section{b. Faktor Substansi Hukum}

Faktor substansi hukum adalah faktor yang berasal dari peraturanperaturan atau ketentuan hukum dalam hal ini peraturan perundang-undangan yang berlaku berkaitan dengan ketentuan hukum acara pidana dalam penerapan keadilan restoratif dalam penyelesaian perkara kecelakaan lalu lintas, di mana saat ini belum ada ketentuan peraturan perundang-undangan yang secara khusus mengatur tentang penerapan keadilan restoratif dalam penyelesaian pidana khususnya perkara kecelakaan lalu lintas. Saat ini petunjuk teknis bagi Penyidik untuk menerapkan keadilan restoratif terdapat dalam Surat Edaran Kapolri Nomor 8 Tahun 2018 tentang Penerapan Keadilan Restoratif (Restorative Justice) Dalam Penyelesaian Perkara Pidana, dan belum diatur dalam ketentuan peraturan perundang-undangan setingkat Undang-Undang, Peraturan Pemerintah maupun Peraturan Kapolri.

Ditinjau dari hirarki peraturan perundang-undangan sebagaimana diatur dalam Undang-Undang Nomor 15 Tahun 2019 tentang Perubahan Atas Undang- 
Undang Nomor 12 Tahun 2011 tentang Pembentukan Peraturan PerundangUndangan, maka Surat Edaran Kapolri Nomor: SE/8/VII/2018 tanggal 27 Juli 2018 tentang Penerapan Keadilan Restoratif (Restorative Justice) Dalam Penyelesaian Perkara Pidana, adalah bukan merupakan kategori peraturan perundang-undangan sebagaimana diatur dalam Pasal 7 dan Pasal 8 undangundang tersebut, sehingga ketentuan yang tercantum Surat Edaran tersebut hanya bersifat peraturan kebijakan (bleidsregel) yang dikeluarkan berdasarkan kewenangan diskresi (discretion power) yang dimiliki oleh aparatur pemerintahan dalam melaksanakan tugasnya. Surat Edaran Kapolri mempunyai perbedaan dengan Peraturan Kapolri yang merupakan jenis peraturan perundang-undangan sebagaimana diatur dalam Pasal 8 Undang-Undang Nomor 12 Tahun 2011, yang dibuat oleh Menteri, Badan, Lembaga atau Komisi yang setingkat yang keberadaannya diakui dan mempunyai kekuatan hukum mengikat sepanjang diperintahkan oleh peraturan perundang-undangan yang lebih tinggi atau dibentuk berdasarkan kewenangan.

Dengan demikian, bahwa Surat Edaran Kapolri Nomor: SE/8/VII/2018 tidak mempunyai kekuatan hukum mengikat bagi Jaksa Penuntut Umum sebagai salah satu sub-sistem dalam wadah sistem peradilan pidana dan merupakan lembaga yang memiliki tugas dan kewenangan untuk melakukan penuntutan terhadap suatu tindak pidana yang terjadi dalam kehidupan masyarakat. Hal tersebut akan membawa konsekuensi bahwa kebijakan Penyidik Unit Laka Lantas untuk tidak melanjutkan penanganan suatu perkara yang telah diselesaikan melalui pendekatan keadilan restoratif dalam hal ini telah terjadi perdamaian antara kedua belah pihak yaitu pelaku dan korban masih dapat dilanjutkan oleh Jaksa Penuntut Umum yang mempunyai kewenangan penuntutan tindak pidana dan tidak wajib untuk mengikuti ketentuan yang tercantum dalam Surat Edaran Kapolri tersebut sehingga akan mengakibatkan terjadinya benturan antara Penyidik dan Jaksa Penuntut Umum dalam penanganan perkara tersebut.

Selanjutnya, dalam Surat Edaran Kapolri Nomor: SE/8/VII/2018 mengatur tentang syarat materiil untuk dapat menerapkan keadilan restoratif dalam penyelesaian tindak pidana, namun Surat Edaran tersebut tidak memberikan batasan tindak pidana apa yang dapat diselesaikan melalui keadilan restoratif. Ketentuan dalam Surat Edaran menyatakan bahwa semua tidak pidana dapat diselesaikan melalui keadilan restoratif kecuali tindak pidana yang 
menimbulkan korban meninggal dunia, dan tindak pidana relatif tidak berat (kesalahan bukan dalam bentuk kesengajaan) dalam hal ini tindak pidana karena kelalaian (delik culpa). Dengan demikian, terhadap perkara kecelakaan lalu lintas yang mengakibatkan korban meninggal dunia tidak dapat diterapkan keadilan restoratif, dan ketentuan tersebut juga dapat menimbulkan multi tafsir dalam penerapannya karena tidak secara eksplisit membatasi ancaman pidana tindak pidana seperti yang diatur dalam Pasal 7 Undang-Undang Nomor 11 Tahun 2012 tentang Sistem Peradilan Anak yang membatasi tindak pidana dengan ancaman pidana di bawah 7 (tujuh) tahun.

Kemudian dalam Surat Edaran Kapolri Nomor: SE/8/VII/2018 mengatur tentang syarat materiil dalam penerapan keadilan restoratif salah satunya mengenai jangka waktu penanganan perkara untuk dapat dilakukan penyelesaian melalui keadilan restoratif yaitu tahap penyelidikan atau tahap penyidikan sebelum Surat Pemberitahuan Dimulainya Penyidikan (SPDP) dikirimkan kepada Jaksa Penuntut Umum. Persyaratan tersebut menjadi kendala dalam penerapan keadilan restoratif karena penerapan keadilan restoratif terhadap suatu perkara perkara pidana penyelesaian melalui keadilan restoratif terhadap perkara kecelakaan lalu lintas kadangkala memerlukan waktu yang cukup lama hingga terjadi kesepakatan perdamaian antara pihak pelaku dan korban sementara penanganan perkara kecelakaan lalu lintas tersebut telah dinaikkan statusnya ke tahap penyidikan dan Penyidik telah mengirimkan SPDP ke Jaksa Penuntut Umum serta telah dilakukan pengiriman berkas perkara tahap I ke Jaksa Penuntut Umum sehingga meskipun antara pelaku dan korban telah terjadi kesepakatan perdamaian terhadap perkara kecelakaan lalu lintas tersebut, namun demikian penyidik tidak dapat menghentikan perkara apabila tidak memenuhi syarat-syarat sebagaimana diatur dalam Pasal 109 ayat 2 KUHAP yaitu karena tidak terdapat cukup bukti, bukan merupakan tindak pidana atau penyidikan dihentikan demi hukum.

\section{c. Faktor Budaya Hukum}

Faktor budaya hukum yang dimaksud sebagai faktor yang mempengaruhi penerapan keadilan restoratif dalam penyelesaian perkara kecelakaan lalu lintas dalam penelitian ini adalah budaya hukum masyarakat yang merupakan faktor yang berhubungan erat dengan nilai-nilai, sikap, perilaku dan kebiasaan hidup 
masyarakat yang mempengaruhi ketaatan terhadap ketentuan peraturan perundang-undangan yang berlaku dalam kehidupan sehari-hari. Dalam hal ini dihubungkan dengan penyelesaian perkara kecelakaan lalu lintas melalui upaya keadilan restoratif, bahwa masyarakat Indonesia pada umumnya berasal dari suku bangsa yang mendiami berbagai daerah dengan berbagai macam etnis beserta budaya masing-masing sehingga sikap dan perilaku masyarakat pada umumnya masih dipengaruhi oleh adat istiadat, budaya dan kearifan lokal yang menjadi pegangan hidup setiap individu dalam menjalani segala aktivitas kehidupan di masyarakat.

Salah satu kebiasaan yang masih dipegang teguh oleh masyarakat Indonesia adalah tradisi musyawarah dan penyelesaian secara kekeluargaan untuk menyelesaikan suatu permasalahan atau perkara pidana yang terjadi dalam kehidupan masyarakat, di mana masyarakat yang terlibat dalam perkara kecelakaan lalu lintas baik sebagai korban maupun pelaku mempunyai pemikiran bahwa penyelesaian perkara kecelakaan lalu lintas yang menimpa dirinya atau keluarganya tidak mesti harus selalu diselesaikan melalui jalur hukum hingga ke pengadilan, namun kadang masyarakat lebih merasakan mendapatkan keadilan apabila penyelesaian perkara kecelakaan lalu lintas tersebut ditempuh melalui jalan musyawarah secara kekeluargaan dengan melibatkan tokoh adat atau tokoh masyarakat setempat berdasarkan nilai-nilai luhur budaya atau adat istiadat yang berlaku dalam kehidupan masyarakat di Indonesia yang dikenal mempunyai karakter atau sikap saling memaafkan satu sama lain ketika terjadi suatu persoalan atau permasalahan antara warga dalam kehidupan di masyarakat.

Namun demikian, bahwa faktor budaya hukum masyarakat tersebut mempunyai perbedaan dalam kehidupan masyarakat antara suatu daerah dengan daerah yang lain, misalnya pada masyarakat yang tinggal di wilayah pedesaan yang masih kental dengan budaya masyarakat yang tradisional beserta kearifan lokal yang masih berlaku dalam kehidupan mayarakat tersebut sehingga mempengaruhi pandangan masyarakat dalam menyelesaikan permasalahan yang terjadi dalam kehidupan masyarakat yang lebih mengedepankan penyelesaian secara kekeluargaan melalui musyawarah mufakat sehingga dapat mengembalikan kehidupan yang harmonins seperti sedia kala yang sempat terganggu akibat dari tindak pidana yang terjadi. 
Budaya hukum masyarakat di pedesaan tersebut tentunya berbeda dengan budaya hukum masyarakat yang tinggal di kawasan perkotaan yang sudah terpengaruh dengan dampak negatif perkembangan kehidupan yang semakin moderen sehingga menumbuhkan sikap dan perilaku yang individualistis dalam kehidupan sehari-hari yang mempengaruhi cara pandang dan sikap dalam menyelesaikan permasalahan yang dialaminya dalam kehidupan masyarakat yang memiliki kecenderungan untuk menyelesaikan permasalahan yang dialaminya melalui proses peradilan pidana yang dianggap lebih memberikan kepastian hukum dibandingkan dengan penyelesaian secara kekeluargaan atau musyawarah mufakat sehingga penerapan keadilan restoratif tidak dapat menyelesaikan perkara tersebut.

\section{PENUTUP}

\section{A. Simpulan}

Berdasarkan uraian pembahasan sebagaimana telah dikemukakan sebelumnya, dapat disimpulkan sebagai berikut:

1. Penerapan keadilan restoratif dalam penyelesaian perkara kecelakaan lalu lintas berat di Polres Metro Jakarta Pusat dilaksanakan oleh Penyidik Unit Laka Lantas pada tahap penyidikan sedang berlangsung setelah adanya surat perjanjian perdamaian antara pihak keluarga pelaku dan korban sehingga Penyidik Unit Laka Lantas tidak melanjutkan penanganan perkara kecelakaan lalu lintas tersebut ke Jaksa Penuntut Umum. Kebijakan Penyidik untuk menerapkan keadilan restoratif tersebut tidak memenuhi syarat materiil, syarat formil dan mekanisme sebagaimana diatur dalam Surat Edaran Kapolri Nomor 8 Tahun 2018 tentang Penerapan Keadilan Restoratif (Restorative Justice) Dalam Penyelesaian Perkara Pidana, di mana syarat materiil bahwa penyelesaian perkara melalui keadilan restoratif dilakukan sebelum Surat Pemberitahuan Dimulainya Penyidikan (SPDP) dikirimkan ke Jaksa Penuntut Umum dan syarat formiil bahwa penerapan keadilan restoratif dilakukan terhadap semua tindak pidana yang tidak menimbulkan korban manusia dalam hal ini korban meninggal dunia, serta penerapan keadilan restoratif terhadap tindak pidana yang terjadi dapat diterapkan setelah melalui mekanisme Gelar Perkara khusus sebagai dasar bagi Penyidik untuk mengeluarkan Surat Perintah Penghentian Penyidikan dan Surat Ketetapan 
Penghentian Penyidikan untuk memberikan kepastian hukum dalam penanganan perkara tersebut.

2. Faktor-faktor yang mempengaruhi penerapan keadilan restoratif dalam penyelesaian perkara kecelakaan lalu lintas berat di Polres Metro Jakarta Pusat terdiri dari faktor penegak hukum, faktor substansi hukum dan faktor budaya hukum. Faktor penegak hukum yaitu pemahaman Penyidik Unit Laka Lantas Polres Metro Jakarta Pusat terhadap ketentuan peraturan perundangundangan yang berlaku berkaitan dengan penyelidikan dan penyidikan perkara kecelakaan lalu lintas, khususnya ketentuan tentang penerapan keadilan restoratif dalam penyelesaian perkara pidana. Faktor substansi hukum yaitu materi peraturan perundang-undangan yang mengatur tentang penerapan keadilan restoratif yang diatur dalam Surat Edaran Kapolri Nomor 8 Tahun 2018 tentang Penerapan Keadilan Restoratif (Restorative Justice) Dalam Penyelesaian Perkara Pidana, di mana Surat Edaran Kapolri bukan merupakan kategori peraturan perundang-undangan sehingga tidak mempunyai kekuatan hukum mengikat bagi Jaksa Penuntut Umum berkaitan dengan kewenangan untuk melakukan penuntutan terhadap perkara kecelakaan lalu lintas yang telah dihentikan penyidikannya oleh Penyidik. Selain itu, substansi Surat Edaran Kapolri tersebut mengatur tentang syarat materiil yang tidak mengakomodir penyelesaian perkara kecelakaan lalu lintas dengan korban manusia dan syarat formiil tentang masalah jangka waktu dalam penerapan keadilan restoratif hanya terhadap tindak pidana pada tahap penyidikan sebelum dikirimkan SPDP, dan harus melalui mekanisme Gelar Perkara khusus sebagai dasar untuk mengeluarkan Surat Perintah Penghentian Penyidikan dan Surat Ketetapan Penghentian Penyidikan. Faktor budaya hukum berkaitan dengan nilai-nilai, sikap, perilaku setiap individu dalam masyarakat yang menjadi pandangan atau pedoman dalam menjalani kehidupan dalam masyarakat sehingga mempengaruhi pengambilan keputusan untuk menyelesaikan perkara kecelakaan lalu lintas yang dialaminya melalui penerapan keadilan restoratif.

\section{B. Saran}

Berdasarkan temuan-temuan hasil penelitian sebagaimana yang telah disimpulkan di atas, disarankan: 
1. Kepada Penyidik Unit Laka Lantas Satuan Lalu Lintas Polres Metro Jakarta Pusat kiranya dapat meningkatkan pengetahuan dan pemahaman terhadap ketentuan peraturan perundang-undangan yang berlaku tentang hukum acara pidana dalam penanganan tindak pidana khususnya tentang penerapan keadilan restoratif dalam penyelesaian perkara pidana sebagai bekal pengetahuan kepada Penyidik Unit Laka Lantas dalam menangani perkara kecelakaan lalu lintas yang terjadi sehingga penerapan keadilan restoratif dalam penyelesaian perkara kecelakaan lalu lintas dapat dilaksanakan sesuai dengan ketentuan peraturan perundang-undangan yang berlaku.

2. Kepada Kepala Korps Lalu Lintas Polri agar berkoordinasi dengan Bareskrim Polri selaku pembina fungsi penyelidikan dan penyidikan tindak pidana dan Divkum Polri selaku pembina fungsi hukum untuk melakukan revisi terhadap Peraturan Kapolri Nomor 15 Tahun 2013 tentang Tata Cara Penangangan Kecelakaan Lalu Lintas yang memberikan pengaturan yang memadai tentang penerapan keadilan restoratif dalam penyelesaian perkara kecelakaan lalu lintas berat yang menimbulkan korban meninggal dunia sehingga dapat menjadi dasar hukum bagi Penyidik Unit Laka Lantas dalam penyelesaian perkara kecelakaan lalu lintas di lapangan

\section{DAFTAR PUSTAKA}

\section{Buku}

Afthonul Afif, Pemaafan, Rekonsiliasi \& Restorative Justice; Diskursus Perihal Pelanggaran di Masa Lalu dan Upaya-Upaya Melampauinya, Pustaka Pelajar, Yogyakarta, 2015.

Bambang Sunggono, Metodologi Penelitian Hukum, Jakarta : PT. RajaGrafindo Persada, 2013.

Burhan Ashshofa, Metode Penelitian Hukum, Jakarta : PT.Rineka Cipta, 2004.

Jonlar Purba, Penegakan Hukum Terhadap Tindak Pidana Bermotif Ringan Dengan Restorative Justice, Jala Permata Aksara, Jakarta, 2017.

Lilik Mulyadi, Media Penal Dalam Sistem Peradilan Pidana Indonesia, Alumni, Bandung, 2015.

Moeljatno, Asas-Asas Hukum Pidana, Rineka Cipta, Jakarta, 2008.

Padmo Wahjono, Indonesia Negara Berdasarkan Atas Hukum, Ghalia Indonesia, Jakarta, 1986.

Peter Mahmud Marzuki, Penelitian Hukum, Jakarta : Kencana, 2013. 
Romli Atmasasmita, Sistem Peradilan Pidana Kontemporer, Kencana, Jakarta, 2011.

Ronny Hanitijo Soemitro, Metode Penelitian Hukum dan Jurimetri, Jakarta : Ghalia Indonesia, 1990.

Teguh Prasetyo, Hukum Pidana, Raja Grafindo Persada, Jakarta, 2011.

\section{Peraturan Perundang-Undangan.}

Undang-Undang Dasar Negara Republik Indonesia Tahun 1945.

Undang-Undang Nomor 8 Tahun 1981 tentang Kitab Undang-Undang Hukum Acara Pidana (KUHAP).

Undang-Undang Nomor 22 Tahun 2009 tentang Lalu Lintas dan Angkutan Jalan.

Undang-Undang Nomor 2 Tahun 2002 tentang Polri.

Undang-Undang Nomor 11 Tahun 2012 tentang Sistem Peradilan Pidana Anak.

Undang-Undang Nomor 15 Tahun 2019 tentang Perubahan Atas Undang-Undang Nomor 12 Tahun 2011 tentang Pembentukan Peraturan Perundang-Undangan.

Peraturan Kapolri Nomor 14 Tahun 2012 tentang Manajemen Penyidikan Tindak Pidana.

Peraturan Kapolri Nomor 15 Tahun 2013 tentang Tata Cara Penanganan Kecelakaan Lalu Lintas.

Surat Edaran Kapolri Nomor: SE/8/VII/2018 tanggal 27 Juli 2018 tentang Penerapan Keadilan Restoratif (Restorative Justice) Dalam Penyelesaian Perkara Pidana.

\section{Sumber Lain.}

Abadi Dwi Saputra, Studi Tingkat Kecelakaan Lalu Lintas Jalan di Indonesia Berdasarkan Data KNKT (Komite Nasional Kecelakaan Transportasi) Dari Tahun 2007-2016, Warta Penelitian Perhubungan, Volume 29, Nomor 2, JuliDesember 2017. 